\title{
Machine tool industry, intellectual property, and gross domestic product
}

\section{Lyudmila Perepechko}

Institute of Thermophysics SB RAS, Head of Innovation Department, Lavrentiev av., 1, Novosibirsk, 630090, Russia

\section{Email address:}

ludmila@itp.nsc.ru

\section{To cite this article:}

Lyudmila Perepechko. Machine Tool Industry, Intellectual Property, and Gross Domestic Product. Journal of World Economic Research. Vol. 3, No. 3, 2014, pp. 21-24. doi: 10.11648/j.jwer.20140303.11

\begin{abstract}
The article presents the investigation results on the relationship between machine tool industry, intellectual property and gross domestic product. In this paper, we considered data from developed countries, BRIC countries, South Korea and Malaysia. It is concluded that the machine tool industry along with the intellectual property is a clear indicator of economic development. For economic growth and enlargement of the gross domestic product, it is important to develop industry and machine tool construction. For Russia's transition to an innovative way, it is necessary to develop the industrial production.
\end{abstract}

Keywords: Machine Tool Industry, Intellectual Property, Gross Domestic Product, Innovative Development

\section{Introduction}

Many economic indicators are used in research for comparing countries, world regions and forecasting economic development. For example, indicators related to technological capital, social capital, science, industry, labor resources are used in [1-3]. Another approach in research is to use only several (even 1 or 2) indicators for measuring economic development. For example, in $[4,5]$ it is proposed to measure innovative development by investments in R\&D only (as a percentage of gross domestic product, GDP). In [6] export growth is considered as indicator of economic development because a rapid export growth accelerates economy.

Therefore, there is the problem to determine the most important indicators of innovation and technological development, which can be used for reliable economic estimates and forecasts. It's desirable to restrict the indicators number by a reasonable limit.

Due to inflation, rising energy prices and rising current prices, the gross world product (GWP) is growing, as well as the GDPs of individual countries. The average annual GWP growth from 1991 to 2012 is $2.2 \%$, and for 22 -year the GWP increased by the factor of 3.08 (data of Economy Watch information portal). Therefore it is not useful to use nominal GWP, it is better to use relative data. Because of that, in this work we considered the shares of GDP of individual countries as a percentage of GWP and then we analyzed the changes these data.

\section{Methods of Investigation}

Indicators related to intellectual property (IP) are important because they are accurate. All national patent offices in their annual reports and on their websites publish the exact number of applications filed, the number of patents in force, and other data. The advantage of the use of IP data in economical research is that the data on IP, patent applications, and the number of patents in each country, which is a member of the World Intellectual Property Organization (WIPO), are reliable, open, accessible and uniform. A patent is a public document and for any patent it is possible to find the authors, copyright holders, country, priority date, area of industry, which is related to the invention, its analogs, and text of application.

From 1991 to 2012 the number of patent applications has increased by a factor of 2.68 (WIPO annual reports http://www.wipo.int/). The national patent office of each country receives as the applications filed by citizens and companies of this country (which are called "residents") as the applications filed by the foreign citizens and companies (which are called "non-residents"). The number of applications filed by non-residents grows faster than that 
filed by residents. In 1991 non-residents filed $34 \%$ of the whole amount of applications. In 2012 they filed $36 \%$ of the whole amount of applications. This process is related to globalization of the economy.

IP that is owned by residents of the country is an indicator of high technologies with export potential. In [7] correlation between the share of applications for patents filed in the U.S. Patent and Trademark Office (IP share) and the share of GDP in the GWP is proved. The indicator of applications for patents in the U.S. Patent and Trademark Office (USPTO) in this work was chosen because the U.S. is the largest economy in the world, and because most applications of nonresidents are filed in USPTO.

Production of metalworking equipment (MWE), or machine tools, is an important indicator of industrial, hightech development. MWE accounts for only a few percents in manufactured goods and in GDP, but machine tool construction is essential for the development of all industries. MWE is the manufacturing base, which includes manufacturing facilities, qualified personnel, and workplace culture [8]. The machine-tool construction determines the scientific and technological progress in the modern world. Production of MWE is capital intensive; it requires highly skilled workforce so it is located mainly in the industrial developed countries. Data on machine tool construction are also reliable because there are analyzes of machine tool companies. For example, the Gardner Business Media, Inc. company (www.gardnerweb.com) publishes annual surveys on the machine tool construction.

In general, it is possible to describe the innovative development of countries economics in terms of four stages. At stage 1 - the borrowing stage - high-tech equipment is imported for production of goods. Then, at the stage of copying (stage 2, developing countries), the equipment starts to be produced in these developing countries. At this stage, the scientific and technical works are carried out to improve existing equipment. At stage 3 (the stage of developed economy, advanced countries), there are developed science and technology, the country starts producing and exporting new high-tech equipment. At stage 4 (post-industrial stage, advanced countries), the advanced countries are engaged into scientific and technical developments, provision of services; they transfer production of industrial goods to developing countries and stop developing its own industry.

Each stage has its own trends in GDP, IP, and MWE dynamics. At the first stage, the country's GDP begins to grow, but it grows only slightly. IP is not protected and MWE is not growing. At the second stage, the GDP grows faster, IP starts being defended, and MWE grows. At the third stage, GDP grows faster, IP grows faster, and MWE grows as quickly as possible. At stage 4, the share of MWE falls, GDP falls, and IP falls.

It is important in order to analyze the development to use not only the absolute characteristics of countries but also the relative ones because namely the position of countries relative to each other determines their competiveness in the world.

As it was noted above both GWP and the number of patent applications are growing every year. MWE production grows also and from 1991 to 2012 increased by the factor of 1.74 .

Therefore, in this paper we considered the shares of GDP as a percentage of GWP, the shares of resident filings at the U.S. Patent Office (IP), and the shares of the countries in the world production of MWE. Not the country's share in the global total production is important but this share's change. A change in the share shows whether the country is developing according to this indicator or not in comparison with other countries. Therefore, the changes of GDP shares, the changes of shares of patent applications and the changes of shares of MWE production in last 18 years are compared: from 1992 to 2000 and from 1992 to 2009. Data are considered since 1992, the year when Russia entered the international arena as an independent state.

The G7 countries, BRIC countries, South Korea (as a representative of technologically advanced countries), and Malaysia (as a country which only entered the path of innovative development) were selected for examination.

Data for the analysis were taken from the following sources: GDP data - Economy Watch information portal, (www.economywatch.com / economic-statistics), data on applications for patents in the United States - the annual reports of USPTO, and data on MWE were kindly provided by Gardner Business Media.

\section{Results}

For the selected countries in this work the data of GDP shares as a percentage of GWP are presented in Table 1. For these countries data of shares of IP applications were taken from [7]. In Table 2 data on MWE shares of selected countries as a percentage of total MWE production are given. Malaysia does not produce any appreciable amount of the MWE yet, therefore the data on MWE production by this country are absent in Gardner Business Media Reviews. On the basis of the data from Tables 1, 2 and data from [7] it was possible to calculate the changes the shares of GDP, IP and MWE of selected countries. The results are shown in Table 3.

Table 1. GDP shares of countries in percents.

\begin{tabular}{lllllll}
\hline Country & $\mathbf{2 0 1 3}$ & $\mathbf{2 0 0 9}$ & $\mathbf{2 0 0 5}$ & $\mathbf{2 0 0 0}$ & $\mathbf{1 9 9 5}$ \\
\hline U.S. & 21.89 & 24.10 & 27.63 & 30.78 & 24.86 \\
Japan & 6.94 & 8.68 & 10.01 & 14.63 & 17.88 \\
Germany & 4.85 & 5.70 & 6.07 & 5.85 & 8.04 \\
France & 3.69 & 4.53 & 4.68 & 4.11 & 8.50 & 5.27 \\
\hline
\end{tabular}




\begin{tabular}{llllll}
\hline Country & $\mathbf{2 0 1 3}$ & $\mathbf{2 0 0 9}$ & $\mathbf{2 0 0 5}$ & $\mathbf{2 0 0 0}$ & $\mathbf{1 9 9 5}$ \\
\hline Great Britain & 3.27 & 3.78 & 5.03 & 4.57 & 3.93 \\
Canada & 2.49 & 2.36 & 2.55 & 2.29 & 2.02 \\
Russia & 2.98 & 2.11 & 1.67 & 0.80 & 1.05 \\
China & 12.16 & 8.61 & 4.94 & 3.71 & 2.43 \\
Brazil & 3.31 & 2.80 & 1.93 & 1.99 & 0.35 \\
India & 2.66 & 2.17 & 1.77 & 1.47 & 1.44 \\
Korea & 1.70 & 1.44 & 1.85 & 1.65 & 1.22 \\
Malaysia & 0.44 & 0.35 & 0.31 & 0.29 & 1.78 \\
\hline
\end{tabular}

Table 2. MWE shares of countries in percents.

\begin{tabular}{|c|c|c|c|c|c|c|}
\hline Country & 2013 & 2009 & 2005 & 2000 & 1995 & 1992 \\
\hline U.S. & 5.8 & 6.1 & 5.1 & 9.6 & 11.7 & 8.9 \\
\hline Japan & 14.4 & 12.5 & 25 & 23.9 & 23.5 & 24.6 \\
\hline Germany & 17.2 & 19.3 & 18.5 & 18.8 & 22.6 & 22.5 \\
\hline France & 0.80 & 1.0 & 1.8 & 2.97 & 2.52 & 2.52 \\
\hline Great Britain & 1.04 & 0.78 & 1.36 & 2,11 & 2.66 & 2.82 \\
\hline Canada & 0.94 & 0.77 & 1.8 & 1.39 & 1.04 & 0.87 \\
\hline Russia & 0.25 & 0.41 & 0.31 & 0.26 & 0.46 & 2.35 \\
\hline China & 29.2 & 27.31 & 9.65 & 5.93 & 4.86 & 5.84 \\
\hline Brazil & 1.27 & 1.27 & 1.3 & 1.44 & 1.75 & 0.9 \\
\hline India & 0.77 & 0.5 & 0.54 & 0.38 & 0.53 & 0.57 \\
\hline Korea & 6.2 & 4.9 & 6.6 & 4.6 & 3 & 1.7 \\
\hline Malaysia & - & - & - & - & - & - \\
\hline
\end{tabular}

Table 3. Changes in GDP, IP and MWE shares of countries in percents.

\begin{tabular}{|c|c|c|c|c|c|c|c|}
\hline \multirow[t]{2}{*}{ Country } & \multicolumn{2}{|c|}{$\begin{array}{l}\text { Changes in the GDP share } \\
\text { of the country in GWP } \\
\text { compared with } 1992 \text {. }\end{array}$} & \multicolumn{2}{|c|}{$\begin{array}{l}\text { Changes in the share of applications filed by } \\
\text { residents of the country to the USPTO in the total } \\
\text { number of applications compared with } 1992 \text {. }\end{array}$} & \multicolumn{3}{|c|}{$\begin{array}{l}\text { Changes in the share of MWE } \\
\text { production in the worldwide MWE } \\
\text { production compared with } 1992 \text {. }\end{array}$} \\
\hline & 2000 & 2009 & 2000 & 2009 & 2000 & 2009 & 2013 \\
\hline U.S. & 4.74 & -1.94 & 2.05 & -4.09 & 0.69 & -2.8 & -3.08 \\
\hline Japan & -1.19 & -7.14 & -4.62 & -4.35 & -0.70 & -12.1 & -10.15 \\
\hline Germany & -2.64 & -2.79 & -0.45 & -1.21 & -3.75 & -3.3 & -5.38 \\
\hline France & -1.54 & -1.12 & -0.49 & -0.74 & 0.45 & -1.5 & -1.72 \\
\hline Great Britain & 0.03 & -0.77 & -0.08 & -0.33 & -0.72 & -2.0 & -1.78 \\
\hline Canada & -0.14 & -0.07 & 0.05 & 0.15 & 0.51 & -0.1 & 0.06 \\
\hline Russia & 0.45 & 1.76 & 0.03 & 0 & -2.10 & -1.9 & -2.11 \\
\hline China & 1.70 & 6.60 & 0.03 & 1.44 & 0.10 & 21.5 & 23.36 \\
\hline Brazil & 0.39 & 1.19 & 0.01 & 0.04 & 0.54 & 0.4 & 0.37 \\
\hline India & 0.28 & 0.98 & 0.06 & 0.64 & -0.19 & -0.1 & 0.2 \\
\hline Korea & 0.26 & 0.05 & 1.01 & 4.4 & 2.92 & 3.2 & 4.51 \\
\hline Malaysia & 0.05 & 0.11 & 0.02 & 0.06 & 0 & 0 & 0 \\
\hline
\end{tabular}

The leader by GDP volume over the considered period is the U.S. However, in 1992 the U.S. share of GWP was $26 \%$, and the top three included Japan - $15.8 \%$ and Germany - 8.5\%. In 2013 the U.S. share decreased slightly and it is now about $22 \%$, while China is on the second place - $12 \%$, and Japan dropped to the 3rd place - $7 \%$, Germany has $4.9 \%$. Russia, Brazil and India are demonstrating an increase in GDP and its share.

As for the IP, in recent decades, according to WIPO, there is a "patent race" in the world. In the last 10 years the number of patent applications is growing much faster than GWP. In WIPO Annual Report 2013 data presenting on IP filing activity for 2012 show that patent filings grew by 9.2 percent on 2011 - the fastest growth over the past 18 years. For comparing GWP showed the growth 3.152 percent for 2012 and 3.954 percent for 2011 . It can be proposed that the development of countries occurs due to develop the high industrial technologies and high-tech production. In 1992 the leaders of the national patent offices in terms of submitted applications were Japan (JPO), USA (USPTO) and Korea (KIPO). Since 1992 to 2012 the number of patent applications, submitted to Chinese Patent Office (SIPO), increased by the factor of 20. In 2012 the three leaders of submitted applications changed: SIPO is on the first place, followed by JPO and USPTO. On the other hand, the USPTO has retained its leadership in terms of patents in force: in 2012 in the United States 2.24 million of patents were kept in force; in Japan there were 1.69 million of patents, and in China there 0.875 million of patents. In 2010 for the first time more applications were filed in SIPO than in USPTO. The U.S. residents file more international applications than the Chinese residents. In 2012 the U.S. residents filed 109 thousand applications by the PCT system. SIPO demonstrated in 2011-2012 the fastest growth in the number of patents: $24 \%$ per year, and the largest share of patent applications for: $27.8 \%$ in 2012. What developing countries have in common is the fact that the royalties of companies for the use of borrowed IP 
exceed several times the proceeds from the use of IP, owned by residents of these countries. For example, according to the World Bank in 2010 (http://data.worldbank.org/indicator) the payments for the use of all types of IP (patents, trademarks, copyrights, etc.) in China were $\$ 13.04$ billion, in Russia they were $\$ 4.8$ billion, and in the United States they were $\$ 32.55$ billion. The receipts for the use of proprietary rights of Chinese IP in 2010 were 0.83 billion dollars, Russian - \$0.39 billion, and American - $\$ 107$ billion; i.e., China and Russia are the IP consumers; they borrow foreign IP.

The leaders of MWE production in 1992 were Japan (24.6\%), Germany (22.5\%) and U.S. ( 9\%), see Table 2. In 2013 the world leaders of MWE production became China (29.2\%), Germany is on second place (17.2\%). Japan holds the third position (14.4\%). Other countries produce less than a half of the total MWE.

However the dynamics and further development of the national economy are important.

In the period from 1992 to 2000 U.S. increased the share of GDP, IP and MWE; from 2000 to 2009 these rates have fallen, and it may be suggested that the country is close to the 4 th stage. The rest of the $\mathrm{G} 7$ countries also degrade their performance, which gives the right to assign them to the 4th stage. The exception is Canada, which for the period from 1992 to 2009 slightly increased its share in applications for IP; this indicates the continuation of the 3rd stage and it is confirmed by a slight increase in the MWE share in 2013 by $0.06 \%$ and the $0.45-\%$ increase in the GDP share in 2013.

Among the BRIC countries, China is the state of the fastest development, which increases significantly, its performance several times.

From1992 to 2009 Brazil has improved its performance on GDP and now it has a positive dynamic of IP and MWE production.

India shows the growth of GDP and IP applications, but a decrease in the share of MWE production, which means scientific and technical research and the early stage 2 . Predictions can be made about the positive dynamics in the future production of MWE and acceleration of the GDP growth, confirmed by the growing MWE share in 2013.

Russia shows GDP growth but a decrease in the share of MWE; the share of IP is stable. On the base of these facts it can be assumed that Russia has got high scientific potential and it may be classified at stage 1. Russia's GDP growth is mainly provided by the trade in natural resources and hydrocarbon fuel.

Korea is at the 3rd stage and it shows an increase in all indicators.

Malaysia shows positive GDP and IP dynamics. It is possible to classify this country at the $2^{\text {nd }}$ stage, and it may be that Malaysia will come soon to the world market as a MWE manufacturer.

\section{Conclusions}

Machine-tool production along with the IP is the most important indicator of economic development. The development of machinery is important for economic development and GDP growth. By analyzing GDP, IP, and MWE data, the economic development of countries, both the world's economic leaders and developing countries, can be recognized. It becomes possible to make predictions for further economic development. In 2012 China became the world leader in patent applications and in machine-tool production. It is possible to expect China could become the first economy in the world. U.S. is the world leader by the GDP volume and by the numbers of patents in force. To retain its leading position the United States should develop high-tech industries, especially MWE.

For developing countries, especially for Russia, is urgent to develop its own science and technology and to organize their own industrial production.

\section{References}

[1] Fagerberg, J., Feldman, M., Srholec, M., (2011) "Technological Dynamics and Social Capability: Comparing US States and European Nations". Paper no. 2011/11. Centre for Innovation, Research and Competence in the Learning Economy (CIRCLE), Lund University PO.

[2] Crescenzi, R., Rodríguez-Pose, A., Storper, M., (2007) “The territorial dynamics of innovation: a Europe-United States comparative analysis". Journal of Economic Geography, 7 (6), 673-709.

[3] The Global Innovation Index: Stronger Innovation Linkages for Global Growth, (2012). Soumitra Dutta, INSEAD Editor WIPO.

[4] Romer, P.M., (1990) "Endogenous Technological Change". Journal of Political Economy, 98, 71-102.

[5] Aghion, P., \& Howitt, P., (1992) "A Model of Growth through Creative Destruction”. Econometrica, 60, 323-351.

[6] Heller, P.S., Porter, R. C., (1978) "Export and growth. An empirical re-investigation". Journal of Development Economics, 5, 191-193.

[7] Perepechko, L.N., (2014) "Intellectual Property as an Indicator of National Economic Growth", International Journal of Economic Theory and Application, 1(1), 1-8.

[8] Arnold, Heinrich, (2001) "The recent history of the machine tool industry and the effects of technological change". 200114. University of Munich, Institute for Innovation Research and Technology Management. 